\title{
Protection or Prevention - Conservation Policy and Planning Instruments for Adaptation of Historically Built Areas in Central Europe
}

\author{
Alice Wanner*, Ulrike Pröbstl-Haider \\ University of Natural Resources and Life Sciences, Vienna. Peter-Jordan-Straße 82, 1190 Vienna, Austria
}

Corresponding Author Email: alice.wanner@boku.ac.at

https://doi.org/10.18280/ijdne.150209

Received: 12 January 2020

Accepted: 29 March 2020

\section{Keywords:}

sustainable tourism, historically built areas, adaptation strategies, stakeholder involvement, policy

\begin{abstract}
Historically built areas (HBA) are often seen as an attraction or authentic core of many European cities and towns. Yet their conservation and protection are guided and dictated by laws and instruments which vary in their flexibility and adaptation ability across central European nations. In the paper at hand, the project BhENEFIT is used to assess national level governance systems. First, it is determined whether or not the systems are comparable. The paper continues by determining to what extent the national governance system take historic building stock into account during planning processes. Lastly it determines that stakeholders are a central part of all national governance structures regarding the use of historic building stock for sustainable tourism purposes. To address current short-comings, the development of a clear local strategy for the integration of energy efficiency and tourism into the heritage conservation is recommended.
\end{abstract}

\section{INTRODUCTION}

Built heritage has a twofold purpose in tourism and architecture in general: On the one hand, it offers an attraction in itself, through its aesthetics [1-3]. On the other hand, it gives a location authenticity or ambience [4-6]. Felt in the manner of experience of local history and local identity, built heritage gives visitors an immersive experience that stays with them long after they have left the narrow alleys, grand plazas or promenades behind and returned to their everyday lives.

However, from an urban planning perspective, Historically Built Areas (HBAs) face difficulties when it comes to their holistic conservation and preservation. Mixed ownership means that local authorities cannot steer the developments alone as private ownership is widespread and multiple stakeholders need to come together [7]. These difficulties have already been experienced. Examples of this have been seen in Portugal and European wine tourism for example [8]. In addition, HBA play an important role in cultural heritage and are therefore surveyed and influenced by government authorities and administrative regulations [9-11]. The legal framework these areas are under, affect how they are managed with clear repercussions for tourism [12] but also with strict rules and regulations guiding the preservation and development for the private owners.

Furthermore, HBAs must be considered in different planning steps and the community planning process. The paper at hand compares the situation in different central European countries by analyzing the condition for tourism development in HBA against the legal background, formal planning and governance (in the form of stakeholder requirements). Governance dealing with sustainability and especially energy efficiency in building stock are affecting private owners, as they seek to convert inefficiency in the historic building stock to meet modern day standards. The European Union has recognized that roughly $75 \%$ of historic building stock in
Europe is to be considered inefficient, and that the renovation of these could reduce the EUs total energy consumption by as much as $6 \%$ [13]. The possibility to address these issues stems from the ERDF funded project BhENEFIT in which 12 partners in 7 central European pilot areas, located in Austria (AT), Croatia (HR), Czech Republic (CZ), Hungary (HU), Slovakia (SK), Slovenia (SLO) and Italy (IT), banded together to find innovative solutions to the preservation and maintenance of historic heritage that would address local issues to ensure environmental, economic and social sustainability. To do so, it was vital to investigate the framing conditions and legal background across the participating nations.

Overall, this paper examines whether the frameworks in each of the investigated countries are beneficial or hinder the use and/or revitalization of historically built areas. To do this, three questions were posed:

1 - Is the legal framework for preservation or renovation changes of HBA in regard to tourism the same or comparable between the respective tourism destinations?

2 - Do the planning process in the countries take consideration of the historic building structures/building stock?

3 - Which governance structures influence the use of historic architecture in regard to tourism? Against this backdrop the consequences for a successful maintenance of HBA for tourism purposes in regard to energy efficiency is discussed. The paper visualizes the differences and highlights the respective short comings for conservation and tourism perspectives.

\section{LITERATURE REVIEW}

There is no doubt that built heritage and HBAs are a tourist attraction [14] as they reflect the unique local identity and diversity of a location [15-17]. In tourism, the strong 
association between people and the built environment is manifested [14]. It restores and preserves heritage and identity [18] in a manner which is characterized through non-rivalry and non-exclusiveness as it is open and available to all, both tourist and local [17].

Preserving architectural heritage carries importance for domestic tourism. "For communities, it can strengthen the local economy, increase community pride and stimulate economic growth. [...] Raise awareness on the importance of the cultural, social, and economic value of caring architectural heritage preservation and its impact on domestic tourism" [15:94]. Also, through outside recognition it becomes more worthy of preservation to the locals [18]. The results are a clear economic benefit through soft location factors which raise property value and will assist in growing a cultural tourism segment [16].

Authentic historic architecture is both a good, as a manmade product but also a service as it has a touristic use and value [14]. Combining old and newly creates a space for tourists that is integrated into the local traditions, yet is nice, comfortable and potentially also environmentally friendly [15]. Locally, the preservation of HBA will not only stimulate the growth of cultural tourism, but it also holds importance for the local economic segment of restorers and craftsmen who, acquainted with traditional techniques are an invaluable asset to the authentic restoration and maintenance [16].Such economic benefit cannot be put in numbers $[14,16]$. To ensure that the HBA are preserved will require financial and human resources and long-term commitment.

However, there are also new challenges for preservation and maintaining the quality of life in the HBA and keeping them alive and not only an attractive facade for tourism purposes. Retrofitting historic building stock is a difficult procedure, not only due to the renovation tasks themselves, but also as regulations and conservation policies often work against developments that change exterior or interior features. Retrofitting challenges concerning energy efficiency have been recognized to influence external features such as windows [19], but also when trying to adapt the structures to include renewable energy sources [20].

The Council of Europe has been the most notable supragovernmental institution working on legislation concerning the preservation of cultural heritage [21]. Documents include The Convention for the Protection of Architectural Heritage of Europe (ETS No. 121, Grenada, 1985), The Framework Convention on the value of Cultural Heritage for Society (ETS No. 199, Faro 2005) and The Council of Europe Convention on offences relating to Cultural Property (ETS No. 221, Nicosia, 2017) [22-24]. These are assisted by recommendations No. R (91) on measures to promote the funding of the conservation of the architectural heritage, Recommendation No R (2003)1 on the promotion of tourism to foster the cultural heritage as a factor for sustainable development and Recommendation 266 (2009) on the future of cultural tourism - towards a sustainable model [25-27]. It is through these documents that the council of Europe pursues "integrated conservation". This approach seeks to integrate conservation into urban planning, decision making processes and combine protection and management [17]. The Council of Europe Recommendations continue to use an integrated conservation approach in their recommendations to this day.

The European Commission represents a similar approach to heritage protection. Although separate entities, cooperation between these organizations has been present for decades. The
European Union's stance on heritage was most recently seen during 2018, which was declared the European Year of Cultural Heritage by the EU. Of particular interest to the approach on heritage and tourism was the document on participatory governance [28], in which the growing need for local stakeholder participation was highlighted. This document also points out current lack on research on participative governance on cultural heritage, lacking data and lack of strategic funding.

All of these documents suggest that participation, conservation in good quality, ensuring financial mechanisms, and the integration of the old in the new in a manner which does justice to the cultural and historic importance of the object are of the utmost importance to preservation of HBA for future generations.

However, the literature has identified limitations to the current approaches. Sustainability of these objects also means that they need to be adaptable to current needs, without irreparable damage for the future [14, 18]. Physical alteration will be necessary [29]. To ensure that alteration will comply with values and desires, policy needs to account for preservation and conservation which appeal to the aesthetic value of a construction but also make it possible to increase efficiency [18]. Energy efficiency in buildings can be increased through improved management of the building stock [30], something that will be necessary throughout central Europe in due time [31]. Furthermore, active stakeholder participation has a growing importance with the high stock of private ownership found in HBA [14]. Something that Hmood, Jumaily and Melnik [18] as well as Alnafeesi [15] agree on.

Public investments often prioritize visitors over locals, and private investors follow the highest expected revenue [14]. The main issue arising is the lack of strategy and policy [18] which cause uncertainty in funding, an unclear role of the government in conservation efforts and cause stakeholders to hold back on private investments. It has been shown in the past, that government incentives free up many-fold the investment of the private sector and grow the local job market [16]. It is therefore the role of the government, national or local, to provide funding and economic efficiency to restoration efforts, especially when environmental sustainability and energy efficiency are to be achieved in HBA [17].

\section{METHODOLOGY}

BhENEFIT - an Interreg Central Europe project - provided the opportunity to investigate planning frameworks and processes comparatively across seven European Union countries: Austria (AT), Croatia (HR), Czech Republic (CZ), Hungary (HU), Slovakia (SK), Slovenia (SLO) and Italy (IT). The project partners' locations are depicted in Figure 1. The project itself focused on the management of historically built areas, their maintenance but also on how innovative solutions may be able to optimize building performances in a sustainable way. Project partners formed BhENEFIT in an effort to exchange experiences in coordinate relevant players and integrate the use of innovative technologies in their respective communities. During the project, it quickly became evident that different countries work under very different policies which influence how conservation can take place. With growing interest in these differences, a methodology was developed to capture policy differences. 


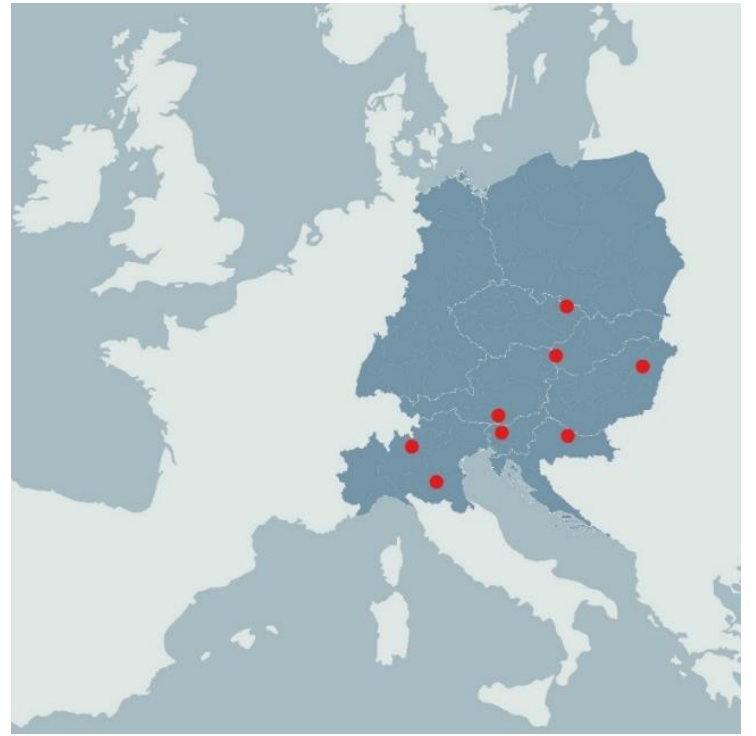

Figure 1. BhENEFIT piloting regions (Interreg Central Europe adapted by Wanner 2020)

All project partners were given a template which was completed in two steps. The first step comprised of a summary of legal and planning frameworks. Each partner brought together technical and public partners, internal and external stakeholders which included interdisciplinary participants and Local Support Groups to fulfill this step. It was crucial for local project partners to complete this step, as documents are often only available in local languages and because they are the ones directly working within these structures. This step included an investigation of national policies approach to historically built areas. It also included a governance analysis including the legal framework, subjects and procedures that define processes specifically concerning built heritage protection, urban planning environmental policies in HBA. Finally, it also gave an overview of governance mechanism and procedures, both national and local, for stakeholder involvement. The tables and written assessments were provided through the Template titled "Assessment of HBA Governance System at National Level" [32]. In order to compare the frameworks, criteria were developed as seen in Tables 1-3, found in the results section of this paper.

The second step was a Strength, Weakness, Opportunity and Threat Analysis (SWOT analysis) conducted by respective pilot regions in regard to the process analysis and stakeholder involvement considering stakeholders such as planning professionals, government officials or affected individuals. More information on this can be found at the paper [32].

\section{RESULTS}

\subsection{Comparability or differences of legal frameworks}

The following results obtained during the research address the comparability of the notions of protection between the countries. It investigates the types of protection categories and the handling of these categories in national and regional planning instruments as well as stakeholder involvement.

\subsubsection{Built heritage protection categories}

In an initial investigation, it was determined that all seven partners have officially protected and non-protected but recognized categories of historically built structures that are considered of national importance. Protected sites included cultural goods and monuments which incorporate archaeological sites, monuments and buildings.

Table 1. Existence of protection categories

\begin{tabular}{cccccccc}
\hline & AT & HR & CZ & HU & IT & SK & SLO \\
\hline Protected & $\mathrm{x}$ & $\mathrm{x}$ & $\mathrm{x}$ & $\mathrm{x}$ & $\mathrm{x}$ & $\mathrm{x}$ & $\mathrm{x}$ \\
Non protected & $\mathrm{X}$ & $\mathrm{x}$ & $\mathrm{x}$ & $\mathrm{x}$ & $\mathrm{x}$ & $\mathrm{x}$ & $\mathrm{x}$ \\
Legal & $\mathrm{x}$ & $\mathrm{x}$ & $\mathrm{x}$ & - & - & $\mathrm{x}$ & $\mathrm{x}$ \\
presumption & & & & & & & \\
Units & $\mathrm{x}$ & $(\mathrm{x})$ & $\mathrm{x}$ & $\mathrm{x}$ & $\mathrm{x}$ & $\mathrm{x}$ & $\mathrm{x}$ \\
Zone & $\mathrm{X}$ & $(\mathrm{x})$ & $\mathrm{x}$ & - & - & $\mathrm{x}$ & $\mathrm{x}$ \\
\hline
\end{tabular}

$\mathrm{x}=$ yes

$(\mathrm{x})=$ partly yes

- = non existent

Responsibility for defining and declaring heritage along with enforcement is found at a Ministry of Culture in Croatia, Czech Republic Italy, Slovakia and Slovenia. Austria and Hungary have federal offices, the Federal Monuments Office and Cultural Heritage Office respectively. Despite the federal structure for heritage protection, in Austria it is still a national responsibility.

Legal presumptions were identified in 5 of the seven countries during the assessment of the governance systems (Table 1). However, Hungary and Italy, the countries without legal presumption indicate that heritage properties are still subject to strict regulation of protection. This however is reflected in the protection of units as opposed to ensembles.

Taking the investigation to a smaller scale, it was determined that heritage protection could be implemented on single units, whole zones or both. The protection of single units such a building or a monument are found in the governance system of all but Croatia. Croatia uses the term "cultural goods" that includes everything from single immovable heritage to landscapes and therefore implies units and ensembles.

Just as in the category of legal presumption all except Hungary and Italy indicate the recognition of zones or ensembles as a category within the governance system. Zoning plans are indicated as the tool used to define these by the corresponding ministries.

All nations also mention the importance of UNESCO world heritage as protection of and recognition of value of HBAs as an important type of protection category.

The protection categories, both UNESCO and national were deemed comparable in the 7 countries as they all show recognition of structures and monuments as worthy of protection. However, there are differences in the legal presumptions, units and ensembles between the countries that inhibit a more exact comparison between them. Therefore, it becomes necessary to investigate the planning instruments to determine to what extent the historic building stock is considered in the maintenance of HBA.

\subsection{Responsibility in planning process urban planning}

The consideration of historic building stock is determined to be recognized in two planning aspects. The first is formal and found in the planning instruments used by local authorities when determining how to deal with historic building stock. The second aspect under which responsibility for historic building stock can be expressed, is in the stakeholders and 
their ability to influence the planning process.

\subsubsection{Planning instruments}

Urban planning typically consists of two spatial levels dedicated to principle land use and respective trade-off. The first level is a land-use plan including zoning, the second is a building code or regulatory plan (usually at a scale of 1:5000). Due to EU regulations [33, 34], all pilot regions are subject to mandatory spatial plans and strategic environmental assessments (SEA) for spatial plans which set the foundation for future developments and also concern tourism, planning or land use. These are flanked by building codes. SEAs for building codes, are not always mandatory. Table 2 illustrates, how few differences there are in use of planning instruments across the regions. The largest discrepancies were identified in the category of non-mandatory spatial concepts which included development programs.

Table 2. Planning instruments used at local level

\begin{tabular}{cccccccc}
\hline & AT & HR & CZ & HU & IT & SK & SL \\
\hline $\begin{array}{c}\text { Land use master } \\
\text { plan/spatial } \\
\text { concept }\end{array}$ & $\mathrm{x}$ & - & $\mathrm{x}$ & $\mathrm{x}$ & $\mathrm{x}$ & $\mathrm{x}$ & $\mathrm{x}$ \\
$\begin{array}{c}\text { Mandatory spatial } \\
\text { plans }\end{array}$ & $\mathrm{x}$ & $\mathrm{x}$ & $\mathrm{x}$ & $\mathrm{x}$ & $\mathrm{x}$ & $\mathrm{x}$ & $\mathrm{x}$ \\
$\begin{array}{c}\text { SEA for spatial } \\
\text { plan }\end{array}$ & $\mathrm{x}$ & $\mathrm{x}$ & $\mathrm{x}$ & $\mathrm{x}$ & $\mathrm{x}$ & $\mathrm{x}$ & $\mathrm{x}$ \\
$\begin{array}{c}\text { Building code } \\
\text { SEA for building } \\
\text { code }\end{array}$ & $/$ & $\mathrm{x}$ & $\mathrm{x}$ & $\mathrm{x}$ & $\mathrm{x}$ & $\mathrm{x}$ & $\mathrm{x}$ \\
\hline
\end{tabular}

$\mathrm{x}=$ yes

$/=$ non mandatory

$-=$ no

* under the expectation of significant impact

** many sectoral plans

Under conditions of change, it was seen that mandatory spatial plans and SEA worked in support of integrating renewable energy sources and for the adaptation for tourism. The assistance of non-mandatory spatial concepts throughout the nations, were found to be of an assistance for local municipalities in Austria, Czech Republic and Hungary. In Italy, the non-mandatory plans were accompanied by many sectoral plans which would include topics of energy, noise and mobility, adding a level of complexity and making them a burden for the process of change. Slovenia and Hungary had no mention of non-mandatory plans being used.

Partners indicated the greatest difficulties in working with rigid building codes and regulations on HBAs, which limited how renewable energy or advancing technology in general, could be applied in historic building maintenance or renovation. This also made the adaptability for tourism purposes incredibly difficult. Some examples of this were seen amongst project partners. In Croatia there are no efforts being made to connect national level regulations with local situations [32:33]. In the Czech Republic and Hungary legislation changes frequent (ibid., 59 \& 84). In Italy, strict regulations are making it nearly impossible to find solutions which both conserve historical constructions and adapt it to daily use, tourism or efficiency adaptations are even further out of reach [32:96]. In Slovakia, the value of cultural heritage is not properly integrated into legal regulation [32:163].

It has been identified, that while the governance and planning systems all recognize historic building stock in protection categories, the incorporation of these into modern planning developments is not taken into consideration. Consideration is only given to protection without consideration of planning processes that could both protect and develop the use of historic building stock. A stalemate is reached at a formal governance level, giving way to a growing importance of how stakeholders use and develop historic properties.

\subsubsection{Funding and support}

In the second step local stakeholders were asked how they perceive the funding and support they get from the locally responsible institutions. In this case at hand, stakeholders are defined as the private owners of historic building stock who are responsible for choices on renovation, upscaling and maintenance of historic building stock unless otherwise noted. The role these stakeholders play in maintaining HBA for touristic purposes varies greatly. There are also great differences in support stakeholders receive from the national institutions responsible for protection of historic structures.

In Austria the level of stakeholder involvement is not legally defined and therefore differs from municipality to municipality. If funding is sought by a stakeholder the Federal Monument Authority can provide support, but this is left to their discretion and decided on a case to case basis. A similar situation is found in the Czech Republic. Here too a case to case cooperation is found. However, the authorities consider municipal representatives as stakeholders as well. In Slovakia, participation was identifies as lacking with room for improvement at a national level, with stronger interest in stakeholder participation growing at the local level. It is seen through the creation of advisory committees, planning workshops and focus groups during which municipality and stakeholders can engage with each other and the HBA. Slovenia and Croatia see stakeholders as responsible for upkeep, access and preservation along with the funding thereof To a certain extent there are cooperation with municipalities. In Croatia stakeholders, as private investors, may be exempt from some communal fees in return for maintenance and upkeep. The Italian stakeholder landscape is characterized by a growing movement with new governance models which promote active stakeholder, NGOs/NPOs and Ordini Professionali participation. In Hungary the definition of stakeholders is expanded to include building authorities, administrators, local committees, planners, churches, national parks and similar institutions. Here, there is also a division between owners (property right practitioners) and the property managers (users).

The assessment of the governance structure is based on the SWOT analysis conducted by pilot region partners in regard to stakeholders' ability to adapt to tourism or renovations to incorporate environmentally friendly integrated tools and renewable energies were categorized in Table 3 . As it was a case to case analysis, not all criteria were relevant in every case. If certain points were unaddressed or not applicable, these were left blank in Table 3.

The hierarchical and legal structure along with the public awareness and engagement of NGOs were determined to be successful factors in the current governance system. Although Italy's legal structure was deemed subpar as already evident from 4.1 and 4.2.1. Hungary and Slovenia also indicate lower levels of public awareness than the other nations.

The governance structures are notably poor concerning stakeholders' ability to interact with political influence, regulation flexibility and guidance by planners during 
conservation processes. Corresponding with 4.2.1 on the difficulties being faced when adapting HBAs to renewable energy or to develop tourism purposes. Furthermore, funding was seen to be lacking, both for public and private investments, and is thus also a shortcoming of the governance structure across central Europe. However, Hungary did not see this in their piloting region and acknowledged funding as acceptable under the current governance structure. On a stakeholder level, the acceptance of historical importance by owners and the impact on tourism are mediocre at best, and show tendencies towards negative ratings. And while awareness of the public on matters of historic conservation are high, it appears to not receive the same recognition in community planning.

During this analysis it became evident, that regulation and public awareness hold a positive and central position in current governance structures throughout central Europe. Yet the practical implementation of community planning developments that would contribute towards touristic developments and improved technology and efficiency are hindered through negative political influence, rigid regulations, and lacking guidance by planners.

Table 3. Criteria for governance structures effecting stakeholders' ability to adapt HBAs to tourism and renewable energy

\begin{tabular}{|c|c|c|c|c|c|c|c|}
\hline Criteria & AT & HR & $\mathbf{C Z}$ & HU & IT & SK & SL \\
\hline $\begin{array}{l}\text { Hierarchal structure } \\
\text { and legal structure }\end{array}$ & ++ & ++ & ++ & + & - & + & + \\
\hline $\begin{array}{l}\text { Engagement of non- } \\
\text { governmental } \\
\text { institutions }\end{array}$ & ++ & & & + & + & & + \\
\hline Public awareness & ++ & - & ++ & & ++ & ++ & - \\
\hline $\begin{array}{l}\text { Education for } \\
\text { craftsman and } \\
\text { engineers }\end{array}$ & ++ & - & ++ & & - & ++ & - \\
\hline $\begin{array}{c}\text { Planning } \\
\text { instruments }\end{array}$ & -- & ++ & & & + & ++ & \\
\hline Data availability & + & - & -- & + & -- & - & \\
\hline $\begin{array}{l}\text { Guidance by } \\
\text { planners }\end{array}$ & -- & & -- & -- & & ++ & - \\
\hline $\begin{array}{c}\text { Awareness in } \\
\text { community planning }\end{array}$ & - & - & & - & ++ & - & - \\
\hline $\begin{array}{c}\text { Acceptance of } \\
\text { history by private } \\
\text { owners } \\
\end{array}$ & -- & & -- & & + & - & - \\
\hline $\begin{array}{c}\text { Impact on tourism } \\
\text { development }\end{array}$ & + & & & -- & & & -- \\
\hline $\begin{array}{c}\text { Regulation } \\
\text { flexibility }\end{array}$ & & + & & -- & -- & -- & - \\
\hline $\begin{array}{l}\text { Incentives \& } \\
\text { funding } \\
\text { opportunities }\end{array}$ & -- & - & -- & + & & -- & - \\
\hline SEA & -- & & & & - & & \\
\hline Enforcing laws & - & & & -- & & -- & \\
\hline $\begin{array}{l}\text { Political influence } \\
\text { into planning } \\
\text { process }\end{array}$ & -- & -- & & -- & & - & \\
\hline
\end{tabular}

$++=$ very good governance structure

$+=$ good governance structures

- = poor governance structures

-- = very poor governance structures

blank $=$ not applicable

\section{DISCUSSION AND CONCLUSION}

Tourism is helpful for maintenance, awareness, income, and land use choice for HBAs [14, 16, 18]. However, the analysis shows great differences across central Europe. Three governance structures have been investigated throughout BhENEFIT: Legal frameworks, official planning instruments and the consideration of owners interests as well as funding opportunities and the role of stakeholders. It has been found that in the case of BhENEFIT, the stakeholders influence the use of HBAs for tourism the most. At national levels, obvious differences in the management of HBA are evident. Italy has the most rigid system concerning the adaptation of HBAs. Austria for example has more variety on a case by case solution. For Austria, protection is an aspect of conservation, how it is implemented practically, however, is an entirely different matter.

The legal framework across central Europe is comparable concerning its fundamental conservation ability. However, the legal framework can hinder the use of HBA for tourism due to its rigidity. While naturally important for conservation reasons, strict regulations were found to be incredibly limiting when it came to upscaling and introducing renewable energy. As a results, HBAs are becoming deserted. Although preserved, they are empty and likely to die without action due to environmental and temporal factors. Alternatively, they may become lively areas which have lost their heritage. The need for adaptability $[14,18]$ is not represented in the legal frameworks of any of the central European project partners. However, it must also be recognized that this protection of built heritage can be vital for its survival in times where stakeholders' acceptance of historic value is low or in communities where guidance planners and political influence is lacking. In the case at hand, the legal framework was also weakened by low levels of law enforcement and lack of proactive involvement of local governance.

The planning processes in the examined countries have moderate differences in consideration of the historic building stock. Planning instruments have little utilization in regard to tourism and renewable energy, as non-governmental institutions are more strongly engaged in the presented case. To ensure the long-term heritage conservation with participative approaches as Alnafeesi [15] suggests, corresponding planning instruments that engage stakeholders need to be added to the currently used instruments. The European Union [28] has started a process of introducing participative instruments in heritage planning, yet research on this continues to be in short supply. The main issue arising concerning planning instruments, is the lack of strategy and policy [18] which would define a clear role for the stakeholders. A discussion on how lax a system can be, without jeopardizing conservation needs to take place. We have seen that Italy's current stance is not a feasible manner to in which to engage stakeholders and encourage adaptation. While Austria's approach may be too lax and threaten authentic building stock in an effort to be too adaptable.

As mixed ownership and land-use characterizes HBAs across Europe, and as this study has found governments are not leading governance on measures concerning tourism or energy efficiency. Therefore, the conservation developments across the studied area vary greatly. What has become clear, is that the role of the stakeholders will need to grow in order to achieve sustainable built heritage conservation. Incentives and funding should be clear and available. Support in local politics should rise. Guidance by expert planners should be available to ensure the legal standards are upheld throughout the HBA and planning instruments are used to their full potential. 
Stakeholders strongly influence how architecture is developed and therefore also for the upkeep of not only the structures but also local culture and local history.

To address current short-comings, the development of a clear local strategy for the integration of energy efficiency and tourism into the heritage conservation is recommended. The strategy should also clearly state the role of local government and stakeholders and measures for mutual support. Funding options should be clear and available. Support can also be shown through incorporation into planning steps or availability of legal advice. Legal frameworks should be adapted in a manner that protect the historic value of the HBA but also allow stakeholders to incorporate new technology and repurposing for tourism. Stakeholders, with their vested interest in developing their properties to serve locals and visitors, are the most important factor in the use of historic structures in regard to tourism.

\section{ACKNOWLEDGMENT}

This work was supported by the European Regional Development Fund (ERDF), Interreg Central Europe Project BhENEFIT.

\section{REFERENCES}

[1] Tulban, N. (2011). Architecture and tourism. J. EcoAgriTourism, 7(2): 67-71. http://rosita.ro/jeat/archive/2_2011.pdf.

[2] March, R.S., Woodside, A.G. (2005). Tourism behaviour: travellers' decisions and actions. Wallingford: CABI. http://dx.doi.org/10.1079/9780851990217.0000

[3] Pröbstl-Haider, U., Haider, W. (2014). The role of protected areas in destination choice in the European Alps. Z. Wirtschgeogr., 58(2-3): 144-163. http://dx.doi.org/10.1515/zfw.2014.0010

[4] Heide, M., Lærdal, K., Grønhaug, K. (2007). The design and management of ambience - Implications for hotel architecture and service. Tour. Manag., 28(5): 1315-1325. http://dx.doi.org/10.1016/j.tourman.2007.01.011

[5] Takanami, A. (2003). The meaning of 'Ambience' in famous hotels in Geneva. Geogr. Rev. Jpn., 76(9): 621644. http://dx.doi.org/10.4157/grj.76.621

[6] Krausler, C., Pröbstl-Haider, U. (2016). Relevance of local Architecture for destination Choice in Austria. Int. J. Sustain. Dev. Plan., 11(3): 426-435. http://dx.doi.org/10.2495/SDP-V11-N3-426-435

[7] Macdonald, S. (2011). Partnerships for the conservation of the historic urban environment. Icomos, 1(1): 893-904.

[8] Dreyer, A. (2015). Weintourismus: Marketing für Weinregionen und Winzer. Elmshorn: ITD-Verlag.

[9] Ripp, M., Rodwell, D. (2016). The governance of urban heritage. Hist. Environ. Policy Pract., 7(1): 81-108. http://dx.doi.org/10.1080/17567505.2016.1142699

[10] Negussie, E. (2016). Implications of neo-liberalism for built heritage management: institutional and ownership structures in Ireland and Sweden. Urban Stud., 43(10): 1803-1824. http://dx.doi.org/10.1080/00420980600838168

[11] Pickerill, T., Pickard, R. (2007). A review of fiscal measures to benefit heritage conservation. RICS Found. Res. Pap. Ser., 7(6).
[12] Hodges, A., Watson, S. (2000). Community-based heritage management: a case study and agenda for research. Int. J. Herit. Stud., 6(3): 231-243. http://dx.doi.org/10.1080/13527250050148214

[13] European Commission. (2019). Energy performance of buildings https://ec.europa.eu/energy/en/topics/energyefficiency/energy-performance-of-buildings/energyperformance-buildings-directive, accessed on Jan. 16, 2020.

[14] Amarilla, B., Conti, A. (2012). Built heritage and sustainable touism: conceptual, economic and social variables. Sustain. Dev. Policy Urban Dev. - Tour. Life Sci. Manag. Environ. http://dx.doi.org/10.5772/28684

[15] Alnafeesi, A.M. (2013). The Role \& Impact of Preservation of Architectural Heritage on Domestiving Tourism. in Proceedings of International Conference on Tourism Development, 2013.

[16] Haspel, J. (2011). Built Heritage as a positive location factor - economic potentials of listed properties. In ICOMOS 17th General Assembly, 2011-11-27 / 201112-02, Paris, France.

[17] Bizzarro, F., Nijkamp, P. (1997). Integrated conservation of cultural built heritage. In P. S. Brandon, P. L. Lombardi, \& V. Bentivegna (Eds.), Evaluation of the Built Environment for Sustainability, Londen: E\&FN Spon, pp. 451-471.

[18] Hmood, K., Jumaily, H., Melnik, V. (2018). Urban architectural heritage and sustainable tourism. In WIT Transactions on Ecology and the Environment, 227: 209220. http://dx.doi.org/10.2495/ST180201

[19] Alves, S., Sendra, J.J. (2015). Evaluating constructive and typological retrofits in solid masonry historic buildings. Struct. Stud. repairs Maint. Herit. Archit., 153: 381-391. http://dx.doi.org/10.2495/STR150321

[20] López, C.S.P., Frontini, F. (2014). Energy efficiency and renewable solar energy integration in heritage historic buildings. Energy Procedia, 48: 1493-1502. http://dx.doi.org/10.1016/j.egypro.2014.02.169

[21] Council of Europe. Most relevant documents of the Council of Europe concerning cultural heritage. https://www.coe.int/en/web/herein-system/council-ofeurope, accessed on Jan. 16, 2020.

[22] Council of Europe, The Convention for the Protection of Architectural Heritage of Europe. ETS No. 121. Grenada, 1985.

[23] Council of Europe, The Framework Convention on the value of Cultural Heritage for Society. ETS No. 199. Faro, Portugal, 2005.

[24] Council of Europe, The Council of Europe Convention on offences relating to Cultural Property. ETS No. 221. Nicosia, Italy., 2017.

[25] Council of Europe, $\operatorname{Rec}(91) 6$ on measures to promote the funding of the conservation of the architectural heritage. 1991.

[26] Council of Europe, $\operatorname{Rec}(2003) 1$ on the promotion of tourism to foster cultural heritage as a factor for sustainable development. 2003.

[27] Council of Europe, $\operatorname{Rec}(2009) 266$ on the future of cultural tourism - towards a sustainable model. 2009.

[28] European Union, Participatory Governance of Cultural Heritage. Publications Office of the European Union. Luxembourg: Publications Ofice of the European Union, 2018. 
[29] Sesana, E., Bertolin, C., Gagnon, A.S., Hughes, J.J. (2019). Mitigating climate change in the cultural built heritage sector. Climate, 7(7): 90. http://dx.doi.org/10.3390/cli7070090

[30] Hambrecht, G., Rockman, M. (2017). International approaches to climate change and cultural heritage. Am. Antiq., $82(4)$ :

$1-15$. http://dx.doi.org/10.1017/aaq.2017.30

[31] Lidelöw, S., Örn, T., Luciani, A., Rizzo, A. (2019). Energy-efficiency measures for heritage buildings: A literature review. Sustain. Cities Soc., 45: 231-242. http://dx.doi.org/10.1016/j.scs.2018.09.029

[32] BhENEFIT, Assessment of HBA Governance System at National Level. Interreg Central Europe, 2018. Online: http://www.central2020.eu/Content.Node/BhENEFITD.T1.1.1-Assessment-of-HBA-governance-system.pdf

[33] European Commission, SEA - Strategic Environmental Assessment VAS for plans and programs. 2001.

[34] European Commission, EIA environmental impact assessment for projects. 1985. 